\title{
PETROLOGY OF THE METAMORPHIC ROCKS (GRAVELS) FROM BHAJANPUR AREA IN PANCHAGARH DISTRICT, BANGLADESH
}

\author{
Md. Rahat Hossain, Ismail Hossain*, A.S.M. Zahid Hossain and Prodip Kumar Biswas ${ }^{1}$ \\ Department of Geology and Mining, University of Rajshahi, Bangladesh \\ ${ }^{1}$ Institute of Mining, Mineralogy and Metallurgy (IMMM), Joypurhat, Bangladesh \\ *Corresponding author; email: ismail_gm@ru.ac.bd
}

\begin{abstract}
The present study deals with petrology of the detrital gravelly rocks from Bhajanpur area, Panchagarh, Bangladesh. The results of detailed petrography of gravelly rocks indicate the presence of quartz (monocrystalline and polycrystalline quartz), K-feldspar, plagioclase, chlorite, muscovite and biotite as major mineralogical compositions. Other minor minerals are garnet, kyanite, graphite and opaque minerals. Based on definitive mineral assemblages, blueschist and greenschist facies sequences are recognized. Correspondingly, index minerals provide chlorite zone, biotite zone, garnet zone, kyanite zone, and graphite zone. The $\mathrm{P}-\mathrm{T}$ conditions of the studied rocks demonstrate the possible temperature ranges $300-550^{\circ} \mathrm{C}$ and pressure ranges $2-10 \mathrm{kbar}$. Most common varieties of metamorphic rocks in the study area are garnet mica schist, chlorite schist, gneiss and few quartzites. Characteristics of garnet mica schist and chlorite schist are equivalent with the lesser Himalayan metamorphic rock sequence in Sikkim area, whereas gneiss from Bhajanpur area has similar precursor as Darjeeling gneiss. Therefore, the sources of detrital metamorphic rocks in Bhajanpur area obviously come from the lesser Himalayan sequence in Sikkim and Darjeeling areas, India.
\end{abstract}

Key words: Petrology, metamorphic rocks, gravels, P-T conditions, Panchagarh, lesser Himalayan sequence

mú isk: eZ Q Q M M

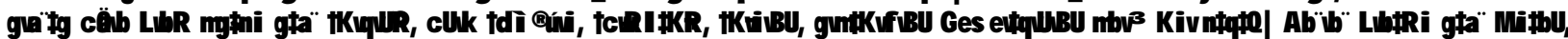

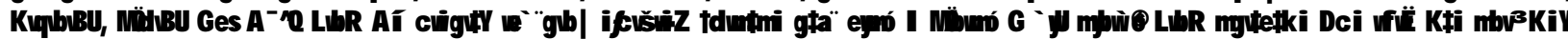

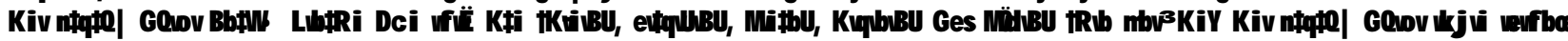

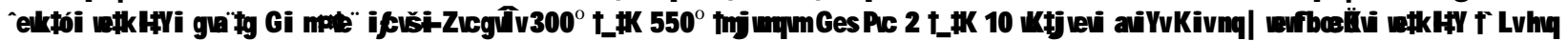

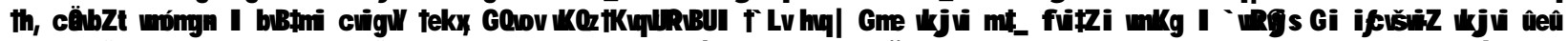

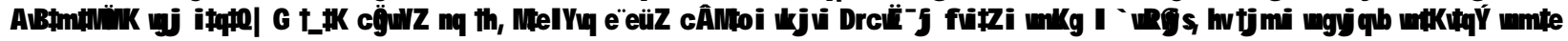
C W WPZ

\section{Introduction}

Petrology of the metamorphic rocks from Panchagarh District, Bangladesh is a pioneer approach for dealing with their mineralogy, texture, field occurrence, metamorphism and their isogradic relationship to Himalayan metamorphic sequences. Metamorphic rocks were deposited scatterly as detrital gravel size particles around the Bhajanpur area, Panchagarh district, just at the sub-Himalayan foothill, northwestern part of Bangladesh. Geographically the area is bounded between latitude $26^{\circ} 25^{\prime} \mathrm{N}$ and $26^{\circ} 38^{\prime} \mathrm{N}$ and longitude $88^{\circ} 20^{\prime}$ and $88^{\circ}$ 33' E (Fig. 1). Although several petrological studies on metamorphic rocks are available in Darjeeling and Sikkim areas, India, in vicinity of the study area (Goscombe and Hand 2000; Neogis et al. 1998; Ganguly et al. 2000: Daniel et al. 2003), there is no systematic petrological study on metamorphic rocks has been carried out in the area, except few sedimentogical works ((Alam 1992; Monsur 1994; Rahman et al. 2004; Rahman et al. 2005). In this study, we attempted to identify the mineralogical assemblages, fabric, metamorphic facies and zone with possible P-T (pressure-temperature) conditions, and consistent isograds with Himalayan metamorphic sequences.

\section{Geological setting}

The study area occupies the northwestern part of Bengal Basin, near the apex of Tista fan of the Himalayan foothill. Tectonically the study area lies in subHimalayan foredeep and Indian platform area (Morgan and Mclntire 1959; Bakhtine 1966; Guha 1978; Khan 1991; Khan and Rahman 1999; Reimann 1993; Khan et al. 1999). Structurally the study area falls in the Dinajpur slope which is geologically identified as "subHimalayan foredeep" of the Bengal Basin. The northsouth Malda-Kishagang fault, with an appreciable down through on the western side (Krisnan 1982), seems to control the entire course of the Mahananda river which originates in the Darjeeling Himalayas and flows south to join the Ganges. According to Burke and Dewey (1973) and Mukhopadhay (1986), the fault forms subsurface north-south striking Ganges delta Graben which extends along the western part of Bengal Basin from the coast up to the foothills of Darjeeling Himalaya. 
Two lithostratigraphic units have been identified in the study area. These are (i) Upper unit which consists of sand, silt and clay of various colours, and (ii) Lower unit consisting of gravel beds, believed to be piedmont deposits (Khan et al. 1990; Khan 1991). This gravel bed, also called Panchagarh gravel (Rahman et al. 2004), comprises mainly pebble, cobble and boulders (Table 1, Fig. 2).

\section{Materials and Methods}

Extensive fieldwork was carried out around the Bhajanpur area, Panchagarh District and different types of gravels from gravel beds were collected. Later on, at least 20 samples were selected for the preparation of petrographic thin sections. Finally, seven different varieties of thin sections were selected for analysis. Each slide was divided into small grids and about 100 to 200 grains were counted by petrographic microscope.

\section{Results and Discussion}

Mineralogical composition: Mineralogical composition of the rock samples were carried out by petrographic analysis and the results of representative minerals are shown in Table 2. Dominant minerals and their physical and optical characteristics are discussed below.

Quartz (Qtz): Qtz appears either as grain or as crystal. It resists all types of chemical weathering. The faces of the mineral are not regular and often distorted. In thin sections, it is colourless. It has low refractive indices, first order gray to yellowish gray interference colour and low birefringence. Cleavage is absent but fracture is common (Fig. 3c). Qtz occurs as dominant minerals in all samples, ranging from 35-51\% (average 43\%). Dominant polycrystalline and minor monocrystalline Qtz are very common in the studied rocks.

$K$-feldspar (Kfs): Both orthoclase and microcline are identified. Orthoclase is identified by its Carlsbad twining. Orthoclase is often cloudy on account of incipient alteration. On the other hand, microcline is identified by its characteristic cross-hatch twinning, presence of cleavage and refractive index variation (Fig. 3e). Kfs is the second dominant mineral in all samples, ranging from 6-30\% (average 22\%).

Plagioclase ( $\mathrm{Pl})$ : $\mathrm{Pl}$ is mostly albite, and is generally identified by its obvious polysynthetic twining (Fig. 3f). $\mathrm{Pl}$ is only present remarkably in the samples V-2 (15\%) and V-3 (24\%).

Mica: Dominant biotite (Bt) and muscovite (Ms) are present in mica group. Ms is colourless in plane polarized light (PPL) and exhibits flaky appearance with high order pink and blue interference colour under cross polarized light (XPL) (Fig. 3e). It contains maximum $15 \%$ (av. 7\%). Bt shows yellow brown colour and pleochroic in PPL but dark brown to dark interference colour (Fig. 3c, 3f). Bt occurs as the third dominant mineral, ranging from $0-20 \%$ (av. 12\%).

Garnet (Grt): These grains are mostly sub-angular (Fig. 3a). Some grains show conchoidal fractures. The mineral was identified by its high relief, colour, isotropic character and pitted surface. Grt is very rare in the study area, and is present in sample V-4 (5\%) only.

Chlorite (Chl): This mineral was identified by its green or bluish green colour and elongated irregular flaky habits. It exhibits weak pleochroism in the shades of green, low to moderate relief, weak birefringence and undulatory extinction (Fig. 3d). Most of the samples were Chl free except sample V-6, which contained about 35\% Chl.

Kyanite (Ky): The mineral occurs as prismatic grain and shows bladed and long fibrous habits. In plane polarized light it is colorless to pale blue in colour (Fig. 3c) and under cross nicol, it shows grey to black colour. Its relief is high and interference colour is up to first order red. It is only present in sample V-5 (8\%).

Graphite (Gr): $\mathrm{Gr}$ is black and very glazy within reflected light. In PPL, it shows gray colour and in XPL, it exhibits black colour. $\mathrm{Gr}$ is only common in sample V-7 (5\%).

Opaque (Opq): These minerals were identified by their appearance in reflected light, by observing the slide under low to medium power with the light cut off from below by blocking the mirror with the hand. Mostly magnetite and illmenite were identified as Opq minerals (Fig. 3d). These occur as accessory minerals in most of the samples. It ranges from $0-5 \%$ (av. 2\%).

Fabric, Mineral assemblage and classification of metamorphic rock: Textural features of metamorphic rock play a key role in their identification and description. Preferred orientation fabrics such as foliation and lineation are especially important (Miyashiro 1994). Texturally these rocks samples are mostly coarse to fine grained and moderately to poorly sorted. The shapes of the grain are angular to subrounded and sub-angular to sub-rounded. The schistose fabrics are very commonly observed in samples $\mathrm{V}-1, \mathrm{~V}-$ 3, V-4, V-6 and V-7 (Fig. 3a). The mineral assemblages in these rock samples are as follows: $\mathrm{V}-1$ : Qtz + Kfs + 
Table 1. Generalized lithological succession of the investigated area at the Khuniyagong, Bhajanpur, Panchagarh, Bangladesh

\begin{tabular}{|c|c|c|c|}
\hline Age & Age Units & Lithology & Thickness (m) \\
\hline \multirow{4}{*}{} & & Gray and brown silty clay & 0.38 \\
\cline { 3 - 4 } & & Fine to medium grained, brownish yellow sand with silt & 0.56 \\
\cline { 3 - 4 } & \multirow{4}{*}{ Upper } & Medium to coarse grained, yellowish, grayish and brownish gray sand & 0.89 \\
\cline { 3 - 4 } & & Brownish yellow coarse grained sand & 0.41 \\
\cline { 3 - 4 } & & Fine to medium grained, yellowish gray and brownish gray sand with granule (<4mm) & 0.78 \\
\cline { 3 - 4 } & & yellowish gray medium grained sand & 0.61 \\
\cline { 3 - 4 } & & Yellowish brown coarse grained sand & 1.01 \\
\cline { 3 - 4 } & & Medium to coarse grained, yellowish gray and brownish gray sand & 0.71 \\
\cline { 3 - 4 } & Lower & Gravel bed (various colour of boulders, pebbles, cobbles, etc) & Up to 18 \\
\hline
\end{tabular}

Table 2. Mineralogical composition (\%) of the studied rocks

\begin{tabular}{|c|c|c|c|c|c|c|c|c|c|c|c|}
\hline \multirow[b]{2}{*}{ 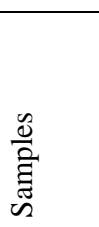 } & \multirow[b]{2}{*}{$\begin{array}{l}\text { 竞 } \\
\text { 号 }\end{array}$} & \multicolumn{2}{|c|}{$\begin{array}{l}\text { FELDSPER } \\
\end{array}$} & \multicolumn{2}{|c|}{ MICA } & \multirow[b]{2}{*}{ 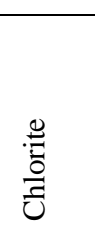 } & \multirow[b]{2}{*}{ 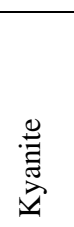 } & \multirow[b]{2}{*}{ 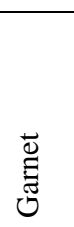 } & \multirow[b]{2}{*}{ 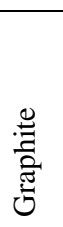 } & \multirow[b]{2}{*}{ 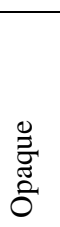 } & \multirow[b]{2}{*}{ 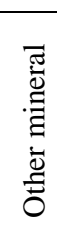 } \\
\hline & & 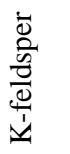 & 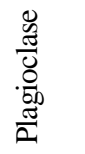 & 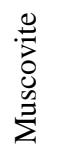 & 苛 & & & & & & \\
\hline $\mathrm{V}-1$ & 51 & 20 & - & 10 & 18 & - & - & - & - & - & 1 \\
\hline $\mathrm{V}-2$ & 45 & 6 & 24 & - & 20 & - & - & - & - & 5 & - \\
\hline V-3 & 46 & 22 & 15 & - & 14 & - & - & - & - & 3 & - \\
\hline $\mathrm{V}-4$ & 44 & 25 & - & 15 & 7 & - & - & 5 & - & 4 & - \\
\hline V-5 & 45 & 24 & - & 10 & 12 & - & 8 & - & - & - & 1 \\
\hline $\mathrm{V}-6$ & 35 & 28 & - & - & - & 35 & - & - & - & 1 & 1 \\
\hline V-7 & 37 & 30 & - & 13 & 12 & - & - & - & 5 & 3 & - \\
\hline
\end{tabular}

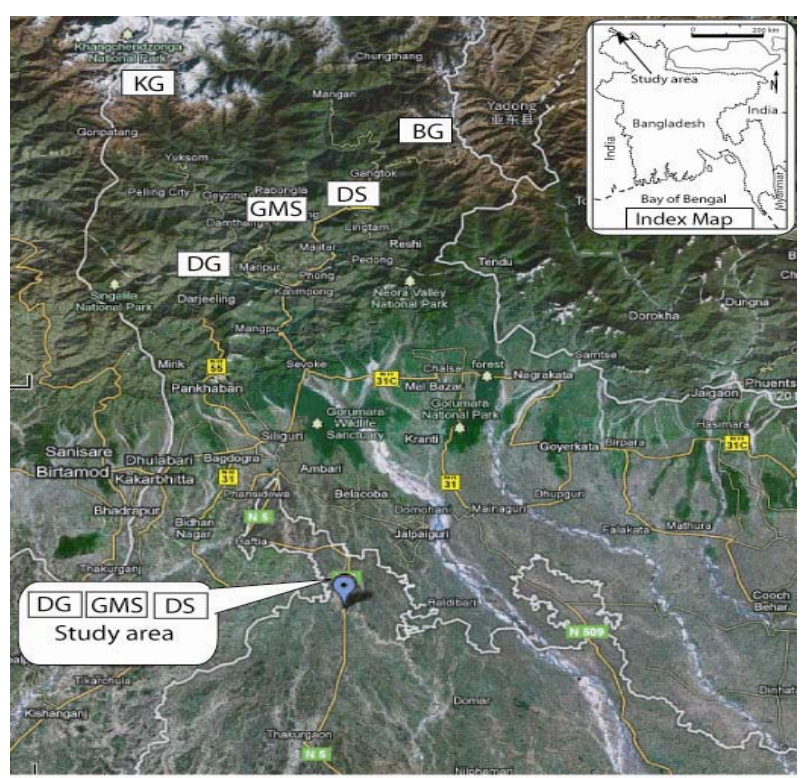

Fig. 1

Location of the study area (Bhajanpur, Tetulia, Panchagarh) and isograds/source rock distributions in the Himalayan sequence (abbr. BG: Barun gneiss, DG: Darjeeling gneiss, DS: Daling schists, GMS: Garnetiferous mica schist, KG: Kanchandzonga gneiss).
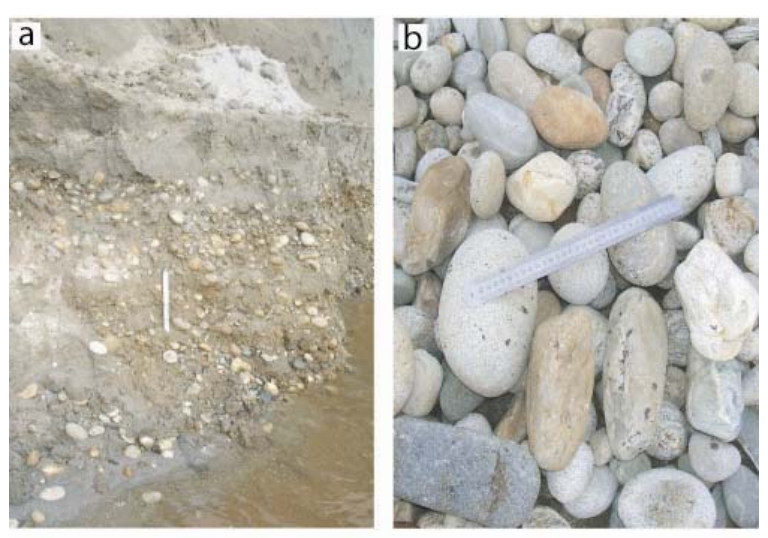

Fig. 2

a) Photograph shows lithological cross section of the khuniyagong in Bhajanpur area, Panchagarh, b) Various sizes of rocks in the study area.

$\mathrm{Ms}+\mathrm{Bt} ; \mathrm{V}-3: \mathrm{Qtz}+\mathrm{Kfs}+\mathrm{Pl}+\mathrm{Bt}+\mathrm{Opq} ; \mathrm{V}-4: \mathrm{Qtz}+$ $\mathrm{Kfs}+\mathrm{Ms}+\mathrm{Bt}+\mathrm{Grt}+\mathrm{Opq}$; V-6: Qtz + Kfs + Chl; and V-7: Qtz + Kfs + Ms + Bt $+\mathrm{Gr}+$ Opq. On the other hand, segregation into light and dark colour band or gneissic band is observed in samples V-2, V-5 (Fig. 3b). 
The mineral assemblages in these rock samples are as follows: V-2: Qtz+ Kfs + Pl + Bt + Opq; and V-5: Qtz + $\mathrm{Kfs}+\mathrm{Ms}+\mathrm{Bt}+\mathrm{ky}$.
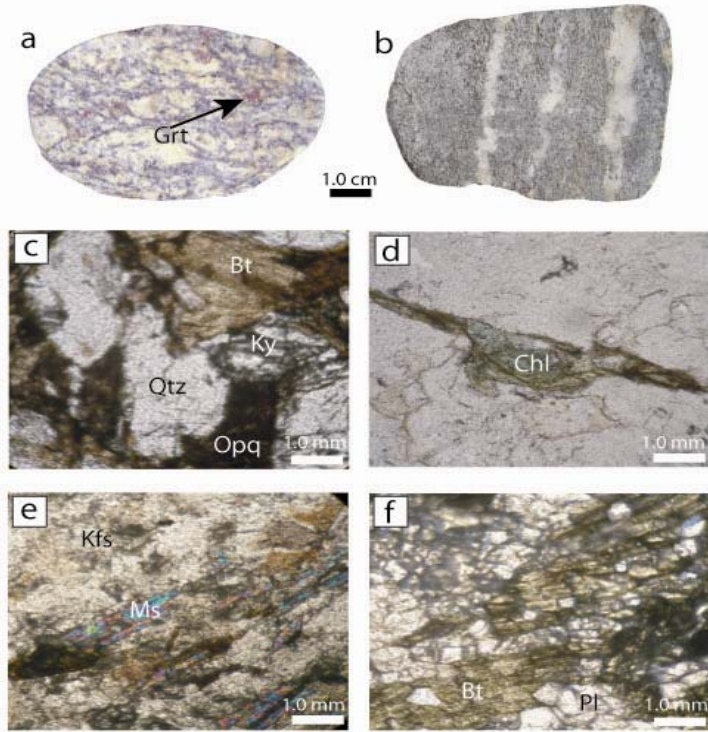

Fig. 3

Macroscopic view of (a) garnet biotite schist, and (b) light and dark colour bands in gneiss. Photomicrographs show (c) Qtz, Bt, Ky, Opq under PPL, (d) Chl under PPL, (e) Kfs, Ms under XPL, and (f) Pl, Bt under XPL.

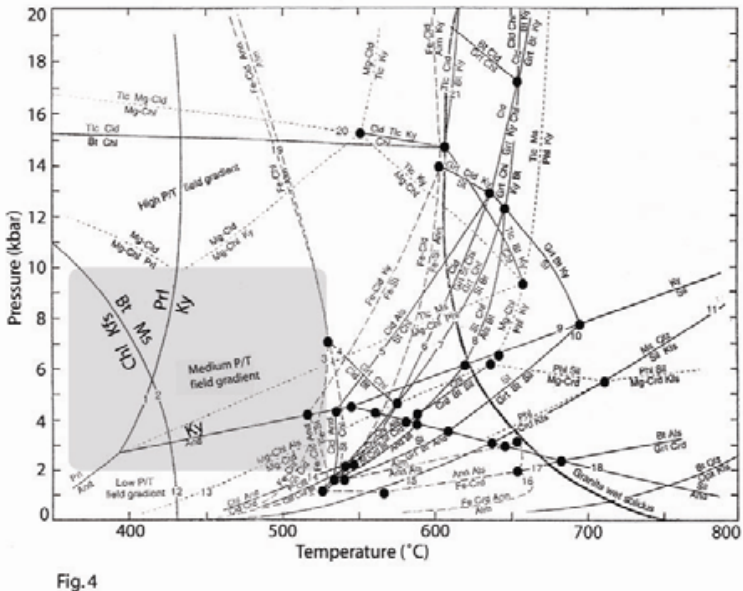

$\mathrm{P}-\mathrm{T}$ conditions of the studied metamorphic rocks, where typical high, medium and low $\mathrm{P} / \mathrm{T}$ metamorphic field gradients are represented in broad shaded area. (Spear and Cheney 1989; Spear 1999).

On the basis of metamorphic fabric and mineral assemblages, the studied rocks were classified as follows:
Schists: Commonly granoblastic to porphyroblastic fine to coarse grained texture, characteristics sub-parallel arrangement of $\mathrm{Bt}, \mathrm{Chl}$ and other platy minerals. Common mineral are Qtz, Kfs, Pl, Bt, Chl, Ky, Ms and Opq. Several varieties of schists are present in the studied area. These are (i) biotite schist, (ii) garnetiferous mica schist, (iii) chlorite schist, and (iv) graphite schist.

Gneiss: The studied gneisses are poorly developed aggregate of light and dark minerals banding. These rocks are generally coarse grained. Sometimes, it contains equidimensional xenoblastic (anhedral) crystal of approximately size with regular polygonal shape or fairly straight boundary meeting at triple junction. Commonly gneiss is composed of Qtz, Kfs, Grt, Bt, Ms and Opq.

Quartzite: This rock is composed of predominately Qtz with very few Kfs and Pl. The rock textures are mostly granoblastic polygonal and undulose extinction is common in polycrystalline Qtz.

Metamorphic facies: Based on the definitive mineral assemblages of the studied rocks, two types of metamorphic facies are identified. These are Greenschist $(\mathrm{Chl}+\mathrm{Pl}+\mathrm{Qtz}+\mathrm{Bt}+\mathrm{Ms})$ and Blueschist $(\mathrm{Qtz}+\mathrm{Pl}+\mathrm{Bt}+\mathrm{Grt})$ facies.

Metamorphic zone: According to index minerals from the studied rock samples, at least five metamorphic zones have been recognized. These are (i) chlorite zone, (ii) biotite zone, (iii) kyanite zone, (iv) garnet zone, and (v) graphite zone, which are the strong indication of immense source area in the Himalayan metamorphic sequences.

Pressure-Temperature $(P-T)$ conditions: In metamorphic petrology, P-T conditions calculation is common phenomena and there are several ways to delineate the P-T conditions for recrystallization of the mineral assemblages. According to definitive mineral assemblages, there are only two types of metamorphic facies are recognized. Those facies have individual P-T conditions. As for examples, Greenschist facies shows pressure range $2-10 \mathrm{kbar}$ and temperature $300-550^{\circ} \mathrm{C}$, and similarly Blueschist facies shows pressure more than $7 \mathrm{kbar}$ and temperature $300-500^{\circ} \mathrm{C}$ (Yardly 1989). Moreover, there are several mineral assemblages, which represent individual $\mathrm{P}-\mathrm{T}$ conditions. Accordingly, mineral assemblage chlorite + albite + garnet in the studied rocks, which indicate low hydrostatic pressure and temperature about $300^{\circ}$ C. Similarly, typical minerals muscovite, biotite and kyanite form moderate 
to high pressure and temperature ranging about 300$500^{\circ} \mathrm{C}$. On the other hand, the mineralogical assemblages in the typical high, medium and low $\mathrm{P} / \mathrm{T}$ metamorphic field gradients (Fig. 4, shaded area) (Spear and Cheney 1989; Cheney 1999) have definite indicative zone for $\mathrm{P}-\mathrm{T}$ conditions. Therefore, the typical minerals in the studied rocks represent possible temperature range about $350-550^{\circ} \mathrm{C}$ and pressure range about 2-10 kbar.

Metamorphic rocks in the Himalaya: Metamorphic rocks in the Himalaya, especially in Nepal, Sikkim, Darjeeling and Bhutan areas, are very common. The Himalayan metamorphic front of two basinal sequences deposited mainly the lesser Himalayan sequence and greater Himalayan sequence.

Lesser Himalayan sequence: In lower Himalaya of Sikkim areas have different varieties of metamorphic rocks. These are (i) Daling schists, which are composed of sericite-chlorite-biotitet-epidote. It indicates Epi to meso grade metamorphic phase, (ii) Garnetiferous mica schist, which is mainly composed of muscovite-biotite-garnet. General increasing trend in metamorphism in this area is often indicated by kyanite-staurolite-garnet to mica schists. It represents a classical meso grade, (iii) Darjeeling gneiss, which is composed of gradually feldspar and layer of quartz which is banded appearance. Most of the feldspars are acid plagioclase which are mostly albite-oligoclase or oligoclase andesine (Gansser et al. 1964).

In lower Himalaya of Bhutan areas comprise mostly amphibolite schists and augen gneiss. Amphibolite schists are found in Wong-chu river. The north-east phuntsholing (SW Bhutan) shows mainly augen gneiss, which main mineralogical composition is perthitic orthoclase with myrmekitic rims surrounded by a mosaic of small quartz, some plagioclase, biotite, sphene and epidote. It reflects a higher grade of metamorphism (Gansser et al. 1964).

In lower Himalaya of Nepal areas have different varieties of metamorphic rocks. In Kushma Formation which consists of quartz-sericite schists and metaquartzite with sub-ordinate amphibolite schists. The compositions of those rocks both have garnet and higher fraction of plagioclase (mainly albite), biotite and rarely kyanite. The Seti Formation consists of sericite-quartz-albite-chlorite schists and phyllite. These schists contain post-kinematic biotite laths and synkinematic garnet, whereas amphibolite schists comprise of plagioclase-epidote-actinolitecalcsilicate (Goscombe et al. 2006).
Higher Himalayan sequence: The higher Himalaya of Nepal areas at the Kali Gandhaki section (in the west) established the following types of metamorphic rocks; (i) Barun gneiss, which is common in the Evarest-Makalu region. The main mineralogical composition of this rock is dominant migmatitic garnet-biotite-sillimanite quartzo-feldspathic units with minor garnet-cordierite-sillimanite metapelite and bands of garnet-hornblende-clinopyroxene mafic gneiss, and (ii) Kangchenjunga gneiss, which is common in the Kangchenjunga region in the far east of Nepal and Sikkim. Compositions of these gneisses are dominated by garnet-sillimanite-cordierite migmatite with minor mafic and similar to the Barun gneiss (Gansser et al. 1964).

\section{Conclusion}

The present work mainly focused on mineralogical composition, mineral assemblages, metamorphic fabric, classification, metamorphic facies and metamorphic zone of detrital metamorphic rocks with possible P-T conditions along with isograds of the source area, which occupies the Northwestern part of Bengal Basin, near the apex of Tista fan at the Himalayan foothill. Tectonically the study area lies in sub-Himalayan foredeep of the Indian platform area. Two lithostratigraphic units have been identified of which the lower unit consists of gravel beds, which believed as piedmont deposits and it is also called Panchagarh gravel, comprising mainly pebble, cobble and boulders size metamorphic rocks.

Major mineralogical compositions of those metamorphic rocks are Qtz (minor monocrystalline and major polycrystalline), Kfs (microcline and orthoclase), $\mathrm{Pl}$ (mostly albite), mica (Ms and $\mathrm{Bt}$ ), Chl. Rarely present Grt, Ky, Gr and Opq. Mineralogical assemblages are very common in both schists and gneisses, except index minerals. According to fabrics and mineral assemblages, schists and gneisses are chief varieties of rocks in the study area with few quartzite. Schists have different varieties, like mica-schist, graphite-schist and garnet-mica schist. Although the definitive mineral assemblages suggest two types of metamorphic facies sequence (Blueschist and Greenschist facies), index minerals display chlorite zone, biotite zone, garnet zone, kyanite zone and graphite zone of the studied rocks. From overall observations of the studied rocks, the possible temperature ranges $300-550^{\circ} \mathrm{C}$ and pressure ranges $2-$ 10 kbar, which is general indication of medium pressure, and low to medium temperature. 
Most common varieties of metamorphic rocks in the study area are garnernetiferous mica schist (Qtz + Kfs + $\mathrm{Ms}+\mathrm{Bt}+\mathrm{Grt}+\mathrm{Opq})$, chlorite schist (Qtz + Kfs + Chl) and gneiss $(\mathrm{Qtz}+\mathrm{Pl}+\mathrm{Bt}+\mathrm{Opq})$. Mineral assemblages of garnernetiferous mica schist are very consistent with the Sikkim areas schists. On the other hand, gneiss shows similar mineralogical assemblages and fabrics with the Darjeeling gneiss. Besides, very common chlorite schist in the study area has common ancestor to the Daling schist in the Sikkim area of the lesser Himalayan sequence (Fig. 1). In the study area, there are no similar metamorphic rock types with higher Himalayan sequence. Accordingly, the detrital metamorphic rocks in Bhajanpur area were obviously come from the lesser Himalayan sequence in the Sikkim and Darjeeling areas, India.

Acknowledgements: We wish to thank the Chairman, Department of Geology and Mining, University of Rajshahi for allowing us to use facilities. We also thank Dircetor, Institute of Mining, Mineralogy and Metallurgy (IMMM), Joypurhat, Bangladesh for their laboratory support. We are also grateful to Dr. M. Nazim Zaman, Principal Scientific officer, Institute of Mining, Mineralogy and Metallurgy (IMMM), Joypurhat, Bangladesh for his kind cooperation. We acknowledge the constructive reviews and comments of anonymous reviewers.

\section{References}

Alam MS. 1992. Trends in grain-size measure and mineralogical analysis of Mahananda and Karatoya river sands of Tetulia Bhajanpur area, Panchagarh Bangladesh. Unpubl M.Sc. Thesis, Department of Geology and Mining, University of Rajshahi. 167pp.

Bakhtine MI. 1966. A speculative tectonic history of Pakistan and surroundings, Some constraints from the Indian Ocean: Geodynamics of Pakistan, pp. 5-24.

Burke K, Dewey JF. 1973. Plume-generated triple junctions: Key indicators in applying plate tectonics to old rocks. J Geol 81, 406-433.

Daniel CG, Hollister LS, Parrish RR, Grujic D. 2003. Exhumation of the Main Central Thrust from Lower Crustal Depths, Eastern Bhutan Himalaya. J Meta Geol 21, 317-334.

Ganguly J, Dasgupta S, Cheng W, Neogi S. 2000. Exhumation history of a section of the Sikkim Himalaya, India: records in the metamorphic mineral equilibria and compositional zoning of garnet. Earth Planet Sci Let 183, 471-486.

Gansser A. 1964. Geology of Himalayas (De Sitter LU ed) Interscience Publishers, John Wiley \& Sons Ltd, London, 289 pp.
Goscombe BD, Hand M. 2000. Contrasting P-T paths in the Eastern Himalaya, Nepal: inverted isograds in a Paired Metamorphic Mountain Belt. J Petrol 41, 1673-1719.

Goscombe B, Gray D, Hand M. 2006. Crustal architecture of the Himalayan metamorphic front in eastern Nepal. Gond Res 10, 232-255.

Guha DK. 1978. Tectonic framework of oil and gas prospect of Bangladesh. Proc. $4^{\text {th }}$ Annual Conf. Bangladesh Geological Soc. Dhaka pp. 65-74

Khan AA, Rahman T. 1992. An analysis of the gravity field and tectonic evaluation of north western part of Bangladesh. Tectonophys 206, 301-655.

Khan FH. 1991. Geology of Bangladesh. Wiley Eastern Ltd, New Delhi, India. 204 pp.

Khan SI, Williams VS, Das SK, Hassan KZ. 1990. Geology of Panchagarh District, Rajshahi Division, Bangladesh. Records of the Geological Survey of Bangladesh, Dhaka, Vol. 6(2).

Krisnan MS. 1982. Geology of India and Burma. CBS Publishers \& Distributors, India. 536 pp.

Miyashiro A. 1994. Metamorphic Petrology. UCL Press Ltd, University College London, Gower Street, London. 331pp.

Monsur MH. 1994. Some geological and economical aspects of the gravel deposits exposed in Dahagram-Panchagarh areas. Bengal Delta 1: 8-9.

Morgan JP, Mclntire WG. 1959. Quaternary Geology of Bangle Basin, East Pakistan and India. Geol. Soc. Am. Bull. 70: 319-342.

Mukhopadhay D. 1986. Structural pattern in the Dharwar craton. J. Geol. 98: 167-186.

Neogi S, Dasgupta S, Fukuoka M. 1998. High-P-T polymetamorphism, dehydration melting, and generation of migmatites and granites in the Higher Himalayan Crystalline Complex, Sikkim, India. J. Petrol. 39: 61-99.

Rahman MA, Alam MS, Islam MA. 2004. Lithostratigraphy and Alluviation History of the Quaternary Deposits in Panchagarh Districts, Northwestern part of Bangladesh. Geosci. J. 10: 13-25.

Rahman MA, Alam MS and Shine FMM. 2005. Roundness and sphericity of clastic sediments of apical part of the Tista Fan in Panchagarh Districts, Bangladesh. Rajshahi Univ. Studies Part B. J. Sci. 33: 153-163.

Reimann KU. 1993. Geology of Bangladesh. Gerbruder Bornt Ramerg, Berlin, Germany. 160 pp.

Sengupta S. 1966. Geological and geophysical studies in the Western part of the Bengal Basin, India. Am. Soc. Geol. Bull. 50(5): 1001-1017.

Spear FS. 1999. Real-time AFM diagrams on your Macintosh. Geol. Mater. Res. 1: 1-18.

Spear FS and Cheney JT. 1989. A petrogenetic grid for pelitic schists in the system $\mathrm{SiO}_{2}-\mathrm{Al}_{2} \mathrm{O}_{3}-\mathrm{FeO}-\mathrm{MgO}-\mathrm{K}_{2} \mathrm{O}-\mathrm{H}_{2} \mathrm{O}$. Contrib. Mineral Petrol. 101: 149-164.

Yardley BWD. 1989. An Introduction to Metamorphic Petrology. Longman, Harlow. 248 pp.

Manuscript received on 26 October 2010 and revised on 20 January 2011 